\title{
KINERJA KEUANGAN DAN TINGKAT PENGEMBALIAN SAHAM: STUDI PADA PERUSAHAAN ASURANSI DI BURSA EFEK INDONESIA
}

\author{
Amalia Rahmawati \\ Universitas Pancasila \\ amaliayeye2@gmail.com
}

\begin{abstract}
Much of the literature said that financial performance had an effect on the stock return, including in insurance company. The purpose of this research is to examine the effect of financial performance to stock return of insurance company that listed in Indonesia stock exchange. This research is using multiple regressions as analysis technique. The results showed that all the variables simultaneously had an effect on the stock return. By partially showed that Price Book Value, Incurred Loss Ratio, Premium Growth Ratio, and Total Asset Turnover has no significant influence on the stock return. While Return on Equity has significant positive influence on the stock return and Debt on Asset Ratio, Net Profit Margin has significant negative influence on the stock return.
\end{abstract}

Keyword: financial performance, stock return, insurance company

\begin{abstract}
Abstrak
Hampir di sebagian besar literatur menyatakan bahwa kinerja keuangan berpengaruh terhadap tingkat pengembalian saham, termasuk pada perusahaan asuransi. Tujuan dari penelitian ini ialah untuk menguji pengaruh kinerja keuangan terhadap perusahaan asuransi yang terdaftar di Bursa Efek Indonesia. Teknik analisis yang dipergunakan dalam penelitian ini ialah regresi berganda. Hasil penelitian menunjukkan bahwa secara simultan seluruh variabel bebas berpengaruh terhadap tingkat pengembalian saham. Sedangkan secara parsial menunjukkan bahwa variabel price book value, rasio beban klaim, rasio pertumbuhan premi, dan total asset turnover tidak berpengaruh terhadap tingkat pengembalian saham. Kemudian, return on equity berpengaruh positif terhadap tingkat pengembalian saham dan debt on asset ratio serta net profit margin berpengaruh negatif terhadap tingkat pengembalian saham.
\end{abstract}

Kata Kunci: kinerja keuangan, tingkat pengembalian saham, perusahaan asuransi

Diterima: 3 Desember 2016; Direvisi: 31 Januari 2017; Disetujui: 10 Februari 2017 


\section{PENDAHULUAN}

Perusahaan Asuransi merupakan lembaga keuangan nonbank yang mempunyai peranan yang tidak jauh berbeda dari bank, yaitu bergerak dalam bidang layanan jasa yang diberikan kepada masyarakat dalam mengatasi resiko yang akan terjadi di masa yang akan datang. Asuransi atau pertanggungan adalah perjanjian dua pihak atau lebih, dengan mana pihak penanggung mengikatkan diri dengan tertanggung dengan menerima premi asuransi untuk memberikan penggantian kepada tertanggung karena kerugian, kerusakan atau kehilangan keuntungan yang diharapkan, atau tanggungjawab hukum kepada pihak ketiga yang mungkin akan diderita tertanggung, yang timbul dari peristiwa yang tidak pasti, atau untuk pembayaran yang didasarkan atas meninggal atau hidupnya seseorang yang ditanggungkan.

Tingkat pengembalian dapat digunakan sebagai alat ukur untuk mengukur keberhasilan perusahaan. Para investor umumnya termotivasi untuk melakukan investasi pada suatu instrumen yang diminati dengan harapan memperoleh tingkat pengembalian investasi yang sesuai. Tingkat pengembalian dapat berupa deviden dan capital gain. Deviden merupakan penerimaan yang berasal dari laba yang dibagikan, sedangkan capital gain merupakan pendapatan yang diperoleh dari selisih harga saham. Apabila selisih harga saham tersebut negatif berarti investor mengalami capital loss dan sebaliknya apabila selisih harga saham tersebut positif maka investor mengalami capital gain. Perusahaan asuransi juga mendapatkan keuntungan investasi.

Asumsi mendasari penelitian ini adalah bagaimana para investor untuk berinvestasi adalah tersedianya informasi yang dapat digunakan dalam melakukan penilaian terhadap suatu investasi. Dalam memperkirakan dan melakukan penilaian surat berharga (saham), investor memperhatikan situasi pasar, namun demikian kinerja perusahaan menjadi faktor yang penting untuk diperhatikan investor. Dalam proses pengambilan keputusan investor cenderung lebih menyukai pengukuran kinerja mencerminkan laba yang tinggi. Analisis fundamental ini adalah usaha untuk memperkirakan kesehatan dan prospek usaha yaitu kemampuan perusahaan untuk tumbuh dan menghasilkan laba di masa depan. Beberapa penelitian dari peneliti yang berbeda tentang pengaruh kinerja 
keuangan terhadap tingkat pengembalian saham masih belum menunjukkan hasil yang konsisten satu sama lain sehingga peneliti tertarik untuk melakukan penelitian yang lebih lanjut terhadap pengaruh kinerja keuangan terhadap Tingkat pengembalian saham pada perusahaan asuransi yang terdaftar di Bursa Efek Indonesia.

Beberapa ukuran kinerja keuangan yang akan dipergunakan dalam penelitian ini ialah return on equity (ROE), debt on asset ratio (DAR), net proft margin (NPM), price book value (PBV), rasio beban klaim (RBK), rasio pertumbuhan premi (RPP), dan total asset turnover. ROE yang semakin meningkat, maka investor semakin tertarik untuk menanamkan dananya ke dalam perusahaan, sehingga harga saham cenderung meningkat. Sebagai dampaknya return saham juga meningkat, dengan demikian ROE berhubungan positif dengan return saham (Susilowati dan Turyanto, 2011). Penelitian Widyawati (2011), Widayanti dan Haryanto (2013) yang menyatakan bahwa DAR berpengaruh signifikan terhadap return saham.

Aset perusahaan yang terlalu banyak berasal dari hutang akan menciptakan risiko bagi perusahaan karena apabila perusahaan menggunakan semakin banyak hutang untuk membiayai aktivanya akan berpengaruh semakin besarnya kewajiban perusahaan baik dalam bentuk kewajiban tetap dan bunga, di lain sisi hutang juga mampu membangun kesempatan untuk meningkatkan kinerja perusahaan (Khoir, dkk, 2013).

Net Profit Margin termasuk dalam salah satu rasio profitabilitas. Semakin tinggi rasio Net Profit Margin berarti laba yang dihasilkan oleh perusahaan juga semakin besar maka akan menarik minat investor untuk melakukan transaksi dengan perusahaan yang bersangkutan. Karena secara teori jika kemampuan emiten dalam menghasilkan laba semakin besar maka harga saham perusahaan dipasar modal juga akan mengalami peningkatan, sehingga secara teoritis NPM berpengaruh positif terhadap return saham (Susilowati dan Turyanto, 2011).

Perusahaan yang mempunyai kinerja bagus maka rasio PBV-nya diatas satu. Hal tersebut menunjukkan bahwa nilai pasar saham lebih besar dari nilai bukunya. Semakin kecil nilai Price to Book Value (PBV) maka harga dari suatu saham semakin murah. Semakin rendah rasio Price to Book Value (PBV) 
menunjukkan harga saham yang lebih murah underprice dibandingkan dengan harga saham lain yang sejenis (Sari dan Kaluge, 2013).

Rasio beban klaim merupakan pengalaman dalam menutup risiko yang telah terjadi serta kualitas usaha penutupan klaim tersebut. Tingkat beban klaim yang tinggi akibat adanya klaim tertentu yang relatif besar akan mengancam kondisi keuangan perusahaan sehingga meningkatkan risiko bagi perusahaan. Tingginya rasio beban klaim memberikan informasi tentang buruknya underwriting dan penerimaan penutupan risiko sehingga dapat berakibat menurunkan harga saham perusahaan asuransi (Kurniawan, 2006).

Tingginya rasio beban tanggungan perusahaan dalam membayar klaim asuransi akan mengakibatkan investor khawatir terhadap kemampuan keuangan perusahaan. Menurut Apsari (2012), Premi netto yang ditunjukkan dengan kenaikan merupakan pertanda bagus yang menunjukkan bahwa pendapatan perusahaan asuransi semakin tinggi. Namun sebaliknya, perusahaan dengan pertumbuhan premi semakin tinggi juga akan mempunyai klaim yang tinggi. Perusahaan senantiasa melihat pertumbuhan premi dengan besar klaim yang terjadi

Perputaran total aktiva menunjukan bagaimana efektivitas perusahaan menggunakan keseluruhan aktiva untuk menciptakan penjualan dalam kaitannya untuk mendapatkan laba. Menurut Astuti (2006) menyatakan bahwa Investor memperhatikan nilai TAT karena nilai penjualan saham industri manufaktur terus meningkat sehingga dengan peningkatan nilai TAT akan meningkatkan pula return yang diterima oleh investor.

\section{METODE}

Penelitian ini menggunakan data kuantitatif, dan merupakan data sekunder. Data sekunder yang digunakan berasal dari laporan keuangan tahunan dan harga saham perusahaan asuransi yang terdaftar pada Bursa Efek Indonesia (BEI). Populasi yang digunakan dalam penelitian ini adalah perusahaan Asuransi yang terdaftar pada Bursa Efek Indonesia (BEI). 
Metode yang dipakai dalam menganalisis variabel-variabel dalam penelitian ini adalah menggunakan regresi linier berganda. Persamaan matematis yang digunakan dalam penelitian ini adalah:

$R S=a+\beta_{1} R O E+\beta_{2} D A R+\beta_{3} N P M+\beta_{4} P B V+\beta_{5} R B K+\beta_{6} R P P+\beta_{7} T A T+\varepsilon$

Dimana: RS ialah return saham; ROE adalah return on equity; DAR ialah debt on asset ratio; NPM ialah net profit margin; PBV ialah price book value; RBK ialah rasio beban klaim; RPP ialah rasio pertumbuhan premi; TATO ialah total asset turnover.

\section{HASIL DAN PEMBAHASAN}

\section{Hasil}

Hal pertama yang dilakukan ialah pengujian asumsi klasik, meliputi: uji normalitas, uji multikolinieritas, uji autokorelasi, dan uji heterokedastisitas. Hasil uji normalitas ditampilkan pada Tabel 1 yang menunjukkan bahwa variabel terikat (RS) dan variabel bebas (ROE, DAR, NPM, PBV, RBK, RPP, TATO) memiliki residual yang terdistribusi normal. Hal ini ditunjukkan dengan nilai signifikasi asymp. sig. (2tailed) sebesar 0.105, lebih besar dari 0,05.

Tabel 1. Hasil Uji Normalitas

\begin{tabular}{|c|c|c|}
\hline & & Unstandardized Residual \\
\hline \multicolumn{2}{|l|}{$\mathrm{N}$} & 55 \\
\hline Normal & Mean & 20,5619 \\
\hline Parameters ${ }^{\mathrm{a}}$,b & Std. Deviation & 10,68301 \\
\hline Most Extreme & Absolute & ,164 \\
\hline \multirow[t]{2}{*}{ Differences } & Positive & ,164 \\
\hline & Negative &,- 119 \\
\hline \multicolumn{2}{|c|}{ Kolmogorov-Smirnov Z } & 1,213 \\
\hline \multicolumn{2}{|l|}{ Asymp. Sig. (2-tailed) } & ,105 \\
\hline
\end{tabular}

Kemudian, berdasarkan Tabel 2, dapat diketahui bahwa semua variabel independen memiliki nilai tolerance lebih besar dari 0,10 dan nilai VIF lebih kecil dari 10. Berdasarkan hasil tersebut, tidak terdapat multikolineritas, 
sehingga data memenuhi kriteria untuk digunakan dalam model regresi.

Tabel. 5. Hasil uji multikolinearitas

\begin{tabular}{|c|c|c|c|}
\hline & \multirow[b]{2}{*}{ Model } & \multicolumn{2}{|c|}{ Collinearity Statistics } \\
\hline & & Tolerance & VIF \\
\hline \multirow[t]{8}{*}{1} & (Constant) & & \\
\hline & ROE & ,268 & 3,736 \\
\hline & DAR & ,222 & 4,513 \\
\hline & NPM & 283 & 3,528 \\
\hline & PBV & ,884 & 1,131 \\
\hline & RBK & ,509 & 1,965 \\
\hline & RPP & ,919 & 1,088 \\
\hline & TATO & ,365 & 2,738 \\
\hline & $\begin{array}{ll}\operatorname{dent} & V \\
\text { er: Hasil out }\end{array}$ & Return & Saham \\
\hline
\end{tabular}

Tabel 3 menunjukan bahwa nilai Durbin-Watson sebesar 1,933. Dengan significance level 0,05, jumlah sampel 55, dan variabel bebas (k) 7, maka pada tabel Durbin-Watson diperoleh nilai dl $(1,2940)$ dan nilai du $(1,8607)$. Nilai Durbin-Watson pada model penelitian berada diantara batas atas (du) dan (4-du), $(1,8607<1,933<2,067)$ maka diperkirakan tidak terjadi pelanggaran autokorelasi.

Tabel. 3. Hasil uji autokorelasi

\begin{tabular}{llrrrr}
\hline Model & $\mathrm{R}$ & R Square & $\begin{array}{c}\text { Adjusted } \\
\text { R Square }\end{array}$ & $\begin{array}{c}\text { Std. Error of the } \\
\text { Estimate }\end{array}$ & $\begin{array}{c}\text { Durbin- } \\
\text { Watson }\end{array}$ \\
\hline 1 &, $557^{\mathrm{a}}$ &, 310 &, 208 &, 41488 & 1,933 \\
\hline
\end{tabular}

a. Predictors: (Constant), TATO, RPP, PBV, RBK, ROE, NPM, DAR

b. Dependent Variable: Return Saham

Gambar 1, diketahui bahwa titik-titik menyebar secara acak serta tersebar baik di atas maupun di bawah angka 0 pada sumbu Y. Oleh karenanya dapat disimpulkan tidak terjadi gejala heteroskedastisitas dalam model regresi. 


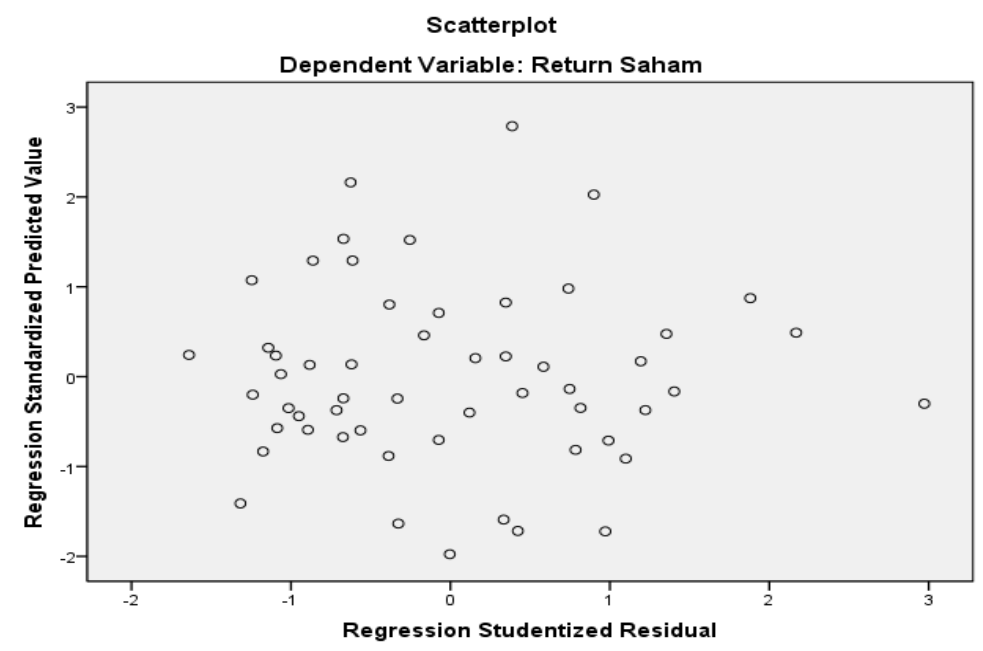

Gambar 1. Hasil uji heteroskedastisitas

Tabel 3 menunjukkan pula nilai koefisien korelasi (R) sebesar 0,557 lebih besar dari 0,5 yang mengindikasikan hubungan antara variabel independen dengan varaibel dependen adalah kuat. Koefisien determinasi (Adjusted R-Square) model regresi dalam penelitian ini adalah 0,208. Artinya, besarnya variasi variabel dependen yang dapat dijelaskan oleh variasi variabel independen adalah sebesar 20,8 \%, sedangkan sisanya sebesar 79,2\% dijelaskan oleh faktor-faktor lain yang dianggap tetap yang tidak dimasukkan ke dalam model regresi.

Tabel. 4. Hasil uji F

ANOVA $^{b}$

\begin{tabular}{llrrrrl}
\hline Model & & Sum of Squares & df & Mean Square & F & Sig. \\
\hline 1 & Regression & 3,639 & 7 &, 520 & 3,020 &, $011^{\mathrm{a}}$ \\
& Residual & 8,090 & 47 &, 172 & & \\
& Total & 11,729 & 54 & & & \\
\hline
\end{tabular}

a. Predictors: (Constant), TATO, RPP, PBV, RBK, ROE, NPM, DAR

b. Dependent Variable: Return Saham

Berdasarkan Tabel 4 menunjukkan bahwa $p$-value $(0,011)$ lebih kecil dari 0,05 . Hal ini mengindikasikan bahwa model regresi layak dan dapat digunakan untuk memprediksi atau variabel independen secara bersama-sama mempengaruhi variabel dependen. 
Tabel. 5. Hasil uji t

\begin{tabular}{|c|c|c|c|c|c|c|}
\hline \multirow{2}{*}{\multicolumn{2}{|c|}{ Model }} & \multicolumn{2}{|c|}{$\begin{array}{c}\text { Unstandardized } \\
\text { Coefficients }\end{array}$} & \multirow{2}{*}{$\begin{array}{c}\text { Standardized } \\
\text { Coefficients } \\
\text { Beta }\end{array}$} & \multirow[b]{2}{*}{$t$} & \multirow[b]{2}{*}{ Sig. } \\
\hline & & B & Std. Error & & & \\
\hline \multirow[t]{8}{*}{1} & (Constant) & 1,235 & ,606 & & 2,038 & ,047 \\
\hline & DAR & $-1,356$ & 672 &,- 519 & $-2,018$ & 049 \\
\hline & ROE & 4,045 & 1,593 & ,594 & 2,539 & ,014 \\
\hline & NPM &,- 029 & 010 &,- 652 & $-2,866$ & ,006 \\
\hline & PBV & 095 & ,071 & ,171 & 1,330 & 190 \\
\hline & RBK & 411 & ,245 & ,285 & 1,677 & 100 \\
\hline & RPP &,- 309 & ,271 &,- 144 & $-1,142$ & ,259 \\
\hline & TAT &,- 554 &, 375 &,- 296 & $-1,478$ &, 146 \\
\hline
\end{tabular}

a. Dependent Variable: Return Saham

Tabel 5 menunjukkan hasil uji, dimana uji $\mathrm{t}$ ini berupaya menunjukkan pengaruh variabel bebas terhadap variabel terikat secara individu. Hasil uji $t$ menunjukkan bahwa hanya variabel DAR, ROE, dan NPM yang berpengaruh terhadap tingkat pengembalian saham. Sedangkan variabel lain seperti PBV, RBK, RPP, dan TAT tidak berpengaruh terhadap tingkat pengembalian saham.

\section{Pembahasan}

Hasil penelitian menunjukkan bahwa Return on Equity (ROE) berpengaruh terhadap tingkat pengembalian Saham (RS). Hasil analisis regresi menunjukkan bahwa ROE memiliki hubungan yang positif terhadap tingkat pengembalian. Apabila ROE naik maka tingkat pengembalian saham juga akan naik. Hasil penelitian ini tidak konsisten dengan penelitian yang dilakukan oleh Hasanah (2008) yang didukung oleh hasil penelitian yang dilakukan Kurniawan (2006) menemukan bahwa ROE secara signifikan berpengaruh negatif terhadap return saham sedangkan penelitian yang dilakukan oleh Susilowati dan Turyanto (2011) ROE tidak berpengaruh terhadap tingkat pengembalian saham.

Hasil ini mengindikasikan bahwa besarnya ROE perusahaan berpengaruh signifikan terhadap tingkat pengembalian saham. Return on Equity merupakan tolak ukur profitabilitas, dimana para pemegang saham pada umumnya ingin mengetahui tingkat probabilitas modal saham dan keuntungan yang telah mereka 
tanam kembali dalam bentuk laba yang ditanam. Apabila saham perusahaan diperdagangkan di bursa saham, tinggi rendahnya Return on Equity akan mempengaruhi tingkat permintaan saham tersebut di bursa dan harga jualnya. Menurut Ngaisah (2008), ketika ROE tinggi maka akan dianggap sebagai informasi yang positif, semakin tinggi ROE menunjukkan semakin efisien perusahaan menggunakan modal sendiri untuk menghasilkan laba atau keuntungan bersih bagi pemegang saham. Dengan demikian ROE dapat mempengaruhi return saham kedepaannya. Hasil penelitian ini konsisten dengan penelitian Widyawati (2011) yang menyatakan bahwa ROE mempunyai pengaruh positif terhadap return saham.

Hasil penelitian menunjukkan bahwa debt to asset ratio (DAR) secara signifikan berpengaruh negatif terhadap Return saham (RS). Pengaruh negatif DAR terhadap tingkat pengembalian saham disebabkan DAR merupakan rasio yang menunjukkan seberapa besar hutang yang dimiliki oleh perusahaan sehingga DAR yang tinggi akan menurunkan tingkat pengembalian saham karena investor bereaksi negatif. Hasil penelitian ini tidak konsisten dengan penelitian yang dilakukan oleh Hasanah (2008) menemukan bahwa DAR secara signifikan berpengaruh positif terhadap tingkat pengembalian saham dan penelitian yang dilakukan oleh Ngaisah (2008) menemukan bahwa DAR tidak berpengaruh secara signifikan terhadap tingkat pengembalian saham.

Tingkat hutang yang semakin tinggi berarti beban bunga akan semakin besar yang berarti mengurangi keuntungan dan juga mengindikasikan tingginya risiko keuangan. Risiko ini terjadi karena pembiayaan perusahaan melalui hutang menimbulkan biaya bunga atas hutang. Jika laba yang dihasilkan tidak mencukupi untuk membayar hutang dan bunganya maka perusahaan akan berada pada posisi default yang dapat mengarah pada kebangkrutan. Akibat dari ini, harga saham akan berubah kearah yang negatif atau turun sehingga tingkat pengembalian saham pun juga akan negatif atau turun (Widyawati, 2011). Hasil penelitian ini konsisten dengan penelitian Widayanti dan Haryanto (2013) yang didukung dengan hasil penelitian yang dilakukan oleh Prasetyo (2013) yang menyatakan bahwa DAR mempunyai pengaruh negatif terhadap tingkat pengembalian saham. 
Hasil penelitian menunjukkan bahwa Net Profit Margin (NPM) secara signifikan berpengaruh terhadap tingkat pengembalian. Tanda negatif pada koefisien NPM menunjukan bahwa setiap peningkatan NPM akan menurunkan return saham. Maka Net Profit Margin (NPM) secara signifikan berpengaruh negatif terhadap Return Saham (RS). Hasil penelitian ini tidak konsisten dengan penelitian yang dilakukan oleh Hasanah (2008) bahwa menemukan bahwa NPM secara signifikan berpengaruh positif terhadap tingkat pengembalian saham, dan penelitian yang dilakukan oleh Susilowati dan Turyanto (2011) dan Mardianti (2012) menemukan bahwa NPM tidak berpengaruh secara signifikan terhadap tingkat pengembalian saham.

Hasil ini menunjukkan bahwa NPM berpengaruh negatif terhadap tingkat pengembalian saham. Kondisi ini menunjukkan tingkat laba bersih yang terjadi pada perusahaan didukung dengan penjualan bersih yang tinggi tetapi menunjukkan biaya yang dikeluarkan perusahaan tidak efisien atau tinggi. Jadi, meskipun nilai NPM perusahaan tinggi menyebakan terjadinya penurunan tingkat pengembalian saham di pasar modal. Seharusnya nilai NPM yang tinggi didukung dengan tingkat efisiensi biaya yang dikeluarkan, sehingga semakin besar tingkat laba bersih, maka daya tarik investor semakin meningkat sehingga tingkat pengembalian saham juga akan meningkat. Hasil penelitian ini konsisten dengan penelitian Heryawan (2013) yang menyatakan bahwa NPM mempunyai pengaruh negatif terhadap tingkat pengembalian saham.

Hasil penelitian menunjukkan bahwa Price Book Value (PBV) tidak berpengaruh terhadap tingkat pengembalian. Hal ini disebabkan takutnya investor membeli saham dengan harga yang rendah yang nantinya berakibat harga saham di masa yang akan datang akan semakin menurun, sehingga akan mempengaruhi tingkat pengembalian perusahaan. Hasil penelitian ini tidak konsisten dengan Nathaniel (2008) menyatakan bahwa PBV berpengaruh terhadap tingkat pengembalian saham. Temuan ini konsisten dan sesuai dengan penelitian yang dilakukan oleh Mutdiyanti (2013) bahwa PBV tidak berpengaruh terhadap tingkat pengembalian saham. Hal ini menunjukkan bahwa perusahaan yang berjalan baik umumnya rasio PBV nya mencapai diatas satu yang menunjukkan bahwa nilai pasar saham lebih besar dari nilai bukunya. Semakin besar PBV semakin tinggi 
perusahaan dinilai oleh para pemodal. Namun dari beberapa kajian PBV yang besar buka merupakan faktor utama dari capaian tingkat pengembalian yang ideal. Terdapat faktor-faktor lain yang turut serta secara langsung ataupun tidak langsung mempengaruhi tingkat pengembalian tersebut.

Hasil penelitian menunjukkan bahwa Rasio Beban Klaim (RBK) tidak berpengaruh terhadap tingkat pengembalian Saham (RS). Rasio beban klaim merupakan pengalaman dalam menutup risiko yang telah terjadi serta kualitas usaha penutupan klaim tersebut. Tingkat beban klaim yang tinggi akibat adanya klaim tertentu yang relatif besar akan mengancam kondisi keuangan perusahaan sehingga meningkatkan risiko bagi perusahaan. Kondisi perekonomian yang kurang stabil sejak krisis ekonomi diduga masih meningkatkan tingkat risiko yang mungkin terjadi sehingga masih memperbesar kemungkinan jumlah klaim dari nasabah secara besar-besaran yang terjadi setiap saat. Proses underwriting yang buruk akan meningkatkan kemungkinan adanya rasio beban klaim yang besar dan dapat mengancam kemampuan perusahaan dalam menghasilkan keuntungan. Berkurangnya kemempuan perusahaaan dalam menghasilkan keuntungan akan mengurangi minat investor dalam membeli saham asuransi dan juga akan meningkatan potensi kebangkrutan perusahaan. Hasil penelitian ini tidak kosisten dengan Kurniawan (2006) bahwa RBK berpengaruh signifikan terhadap tingkat pengembalian saham. Temuan ini konsisten dan sesuai dengan penelitian yang dilakukan oleh Detiana (2012) bahwa RBK tidak berpengaruh terhadap tingkat pengembalian saham.

Hasil penelitian menunjukkan bahwa Rasio Beban Klaim (RPP) tidak berpengaruh terhadap tingkat pengembalian Saham. Hasil penelitian ini tidak konsisten dengan Kurniawan (2006) bahwa RPP berpengaruh signifikan terhadap tingkat pengembalian saham. Temuan ini konsisten dan sesuai dengan penelitian yang dilakukan oleh Detiana (2012) bahwa RPP tidak berpengaruh terhadap tingkat pengembalian saham

Hasil penelitian menunjukkan bahwa TAT tidak berpengaruh terhadap tingkat pengembalian Saham (RS). Tidak signifikannya TAT terhadap return saham disebabkan karena TAT hanya sebagian kecil dari ukuran rasio aktivitas 
perusahaan, yang dijadikan acuan bagi investor untuk mengukur baik buruknya kinerja manajemen dalam meningkatkan penjualan, sedangkan keberhasilan dari penjualan lebih banyak dipengaruhi oleh kegiatan advertensi, promosi. Temuan ini konsisten dan sesuai dengan penelitian yang dilakukan oleh Naryoto (2013) bahwa TAT tidak berpengaruh signifikan terhadap tingkat pengembalian saham. Hasil penelitian ini tidak konsisten dengan penelitian Astuti (2006) bahwa TAT berpengaruh terhadap tingkat pengembalian saham. nilai TAT yang tinggi akan mengurangi ketidakpastian investor dalam menanamkan dananya. Dari penjualan yang tinggi diharapkan dapat dihasilkan return yang tinggi pula. TAT merupakan salah satu ukuran yang digunakan untuk menilai efisiensi manajemen di dalam menjalankan roda perusahaan. TAT yang tinggi mengindikasikan bahwa manajemen perusahaan dapat mendayagunakan seluruh aktiva yang dimilikinya untuk mendatangkan pendapatan bagi perusahaan dan hal ini pada gilirannya dianggap dapat meningkatkan keuntungan perusahaan. Dengan demikian, TATO yang tinggi berpotensi menarik investor untuk terus berinvestasi di perusahaan tersebut dan akan meningkatkan nilai saham tersebut. TAT yang tinggi menunjukkan semakin efisien suatu perusahaan dalam memanfaatkan aktiva yang dimilikinya dan menunjukkan semakin besar penjualan yang dihasilkan, yang kemudian akan berdampak positif pada harga saham.

\section{SIMPULAN}

Hasil pengujian dengan menggunakan regresi linear berganda membuktikan bahwa beberapa kinerja keuangan seperti ROE, DAR, dan NPM berpengaruh terhadap tingkat pengembalian Saham. Sedangkan beberapa variabel kinerja keuangan lainnya seperti: PBV, RBK, RPP dan TATO tidak berpengaruh terhadap tingkat pengembalian saham.

Implikasi dari penelitian ini ialah perusahaan asuransi harus terus mampu meningkatkan kinerja keuangannya. Kinerja keuangan yang semakin baik, akan mampu meningkatkan tingkat pengembalian saham pada perusahaan asuransi. Selain itu kinerja keuangan merupakan salah satu acuan investor dalam memutuskan membeli saham pada perusahaan-perusahaan yang terdaftar di Bursa Efek Indonesia. 


\section{PUSTAKA ACUAN}

Apsari, C. (2012). Analisis Pengaruh Rasio Early Warning System dan Risiko Sistematik Terhadap Harga Saham Pada Perusahaan Asuransi Kerugian yang Terdaftar Di BEI. (Skripsi Tidak Dipublikasikan). Surabaya: STIE Perbanas.

Astuti, S.P. (2006). Analisis Pengaruh faktor-faktor fundamental, EVA, MV terhadap return saham (studi pada perusahaan manufaktur di Bursa Efek Jakarta periode 2001-2003). (Tesis Tidak Dipublikasikan). Semarang: Universitas Diponegoro.

Detiana, T. (2012). Pengaruh Financial Early Warning Signal terhadap Perubahan Harga Saham pada Perusahaan Asuransi yang terdaftar di Bursa Efek Indonesia. Jurnal Bisnis dan Akuntansi. Vol 14, No 3: 239-245.

Hasanah, L. (2008). Analisis pengaruh leverage keuangan dan rasio profitabilitas terhadap return saham pada perusahaan yang terdaftar di JII tahun 20052007. (Skripsi Tidak Dipublikasikan). Yogyakarta: UIN Sunan Kalijaga.

Heryawan, H. (2013). Analisis Pengaruh EPS, NPM, ROA Terhadap Return Saham Perusahaan Sektor Asuransi di Bursa Efek Indonesia. (Skripsi Tidak Dipublikasikan). Jakarta: UIN Syarif Hidayatullah.

Khoir, V.B. dkk. (2013). Pengaruh EPS, ROA, NPM, DAR dan LDER terhadap harga saham (Studi Pada Perusahaan Subsektor Perdagangan yang Terdaftar Di Bursa Efek Indonesia Periode 2010-2012). Jurnal Administrasi Bisnis. Vol. 5, No. $1: 1-12$.

Kurniawan, S. (2006). Analisis Pengaruh Rasio-Rasio Early Warning System dan Tingkat Suku Bunga SBI Terhadap Harga Saham Pada Perusahaan Asuransi di BEJ Tahun 1999-2003 . (Tesis Tidak Dipublikasikan). Semarang: Universitas Diponegoro

Mardianti, R. (2012). Pengaruh EPS, NPM dan ROA Terhadap Return Saham (Studi Pada Perusahaan Food and Beverage yang Terdaftar di BEI). Jurnal Ilmiah Mahasiswa FEB Universitas Brawijaya. Vol. 2, No. 2: 71-80.

Mutdiyanti. (2013). Pengaruh PBV, EPS, ROA dan DER Terhadap Harga Saham (Studi Pada Perusahaan Indeks LQ45 Yang Terdaftar di BEI). (Skripsi Tidak 
Dipublikasikan). Bandung: Universitas Pasundan.

Naryoto, P. (2013). Pengaruh Return On Equity (ROE), Current Ratio (CR), Debt to Equity Ratio (DER), Total Assets Turn Over (TATO) dan Earning Per Share (EPS) terhadap Return Saham. (Skripsi Tidak Dipublikasikan). Jakarta: Universitas Budi Luhur.

Nathaniel, SD. N. (2008). Analisis Faktor-Faktor Yang Mempengaruhi Return Saham: Studi Pada Saham-saham Real Estate and Property di Bursa Efek Indonesia Periode 2004-2006. (Tesis Tidak Dipublikasikan): Semarang: Universitas Diponegoro.

Ngaisah, S. (2008). Pengaruh rasio profitabilitas dan leverage terhadap return saham pada perusahaan yang terdaftar di JII tahun 2004-2006. (Skripsi Tidak Dipublikasikan). Yogyakarta: UIN Sunan Kalijaga.

Prasetyo, A. (2013). Pengaruh Leverage dan Profitabilitas Terhadap Harga Saham Pada Perusahaan Manufaktur yang Terdaftar di Bursa Efek Indonesia Tahun 2009 - 2011. (Skripsi Tidak Dipublikasikan). Tanjung Pinang: Universitas Maritim Raja Ali Haji.

Sari, W. \& D. Kaluge. (2013). Analisis Pengaruh Faktor Fundamental dan Kondisi Ekonomi terhadap Return Saham. Jurnal Ilmiah Mahasiswa FEB Universitas Brawijaya. Vol. 1, No. 2: 51-60.

Susilowati, Y. \& T. Turyanto. (2011). Reaksi Signal Profitabilitas dan Rasio Solvabilitas Terhadap Return Saham Perusahaan. Dinamika Keuangan dan Perbankan. Vol. 3, No.1: 17-37.

Widayanti, P. \& A.M. Haryanto. (2013). Analisis Pengaruh Faktor Fundamental dan Volume Perdagangan Terhadap Return Saham (Studi Kasus Pada Perusahaan Real Estate dan Property yang Terdaftar di BEI periode 20072010). Diponegoro Journal of Management. Vol. 2, No. 3: 1-11.

Widyawati, H. (2011). Pengaruh Ratio Profitabilitas dan Leverage Terhadap Return Saham (Studi Kasus Pada Industri Automotive dan Alliend Product yang Listed di BEI. Dinamika Manajemen. Vol. 2, No. 4: 49-64. 